\title{
STRENGTHENING OF TEACHER PROFESSION THROUGH SUSTAINABILITY MASTER WORKS OF SCIENTIFIC LEARNING
}

\author{
${ }^{1}$ Kemal Budi Mulyono, ${ }^{2}$ Ahmad Jaenudin \\ ${ }^{1,2}$ Universitas Negeri Semarang
}

\section{ARTICLE INFO}

\section{Article History:}

Received January, 30, 2021

Accepted June, 17, 2021

Available June, 302021

\section{Keywords:}

Sustainability Profession, Scientific Papers

\begin{abstract}
Peran guru sesungguhnya juga membutuhkan pengembangan diri. Permasalahan yang dihadapi guru- guru dalam proses pembelajaran adalah keterbatasan pengetahuan pengembangan profesi keberlanjutan terutama untuk menulis karya ilmiah pembelajaran inovatif. Tujuan pengabdian kepada masyarakat in adalah: meningkatkan kompetensi guru dalam menulis karya ilmiah pembelajaran inovatif, dengan adanya pelatihan tersebut maka guru dapat meningkatkan karir kepangkatan serta dapat menciptakan pembelajaran yang inovatif. Solusi pemecahan masalah adalah: sosialisasi serta paparan konsep, membuat permodelan dilanjutkan simulasi model, karena saat ini kita dalam proses pandemic Corona Virus, oleh karena itu yang semula di lakukan secara tatap muka langsung, namun karena masa pandemi pengabdian dilakukan via daring (Dalam Jaringan), dari hal tersebut dilakukan kegiatan pelatihan penulisan penelitian tindakan kelas dan publikasi artikel. Target dari kegiatan pengabdian kepada masyarakat ini berjumlah 65 guru, namun ternyata pada hari pelaksanaan pendaftar meningkat menjadi 250 guru. Metode kegiatan pengabdian dimulai dari workshop pengetahuan dan pemahaman tentang penulisan karya ilmiah pembelajaran inovatif, melalui sesi diskusi dan tanya jawab, simulasi penulisan proposal, serta pendampingan dan monitoring serta evaluasi kegiatan.
\end{abstract}

The role of the teacher actually also requires self-development. The problem faced by teachers in the learning process is the limitation of knowledge of sustainability professional development, especially to write innovative scientific learning works. The purpose of community service is: improving the competence of teachers in writing innovative learning scientific works, with the training, teachers can improve their career rank and can create innovative learning. Problem solving solutions are: socialization and exposure of concepts, making modeling continued model simulation, because we are currently in the process of pandemic Corona Virus, therefore the originally done face-to-face, but because of the pandemic period of devotion is done via online (In Network), from it is conducted training activities writing class action research and article publication. The target of community service activities amounted to 65 teachers, but it turned out that on the day of the implementation of applicants increased to 250 teachers. The method of devotion activities starts from the workshop of knowledge and understanding of the writing of scientific works of innovative learning, through discussion and question and answer sessions, simulation of proposal writing, as well as mentoring and monitoring and evaluation of activities.

Address: L Building, Campus Sekaran, Gunungpati, Semarang, Indonesia, 50229

Correspondent Address:

Universitas Negeri Semarang

Email: sonmuly@mail.unnes.ac.id 


\section{INTRODUCTION}

Globalization has given birth to pressures, where the quality of the human being will be the winner and the weak will be the loser. The winning group is educated, personally autonomous, skilled, highly adaptability, has strong economic capabilities, and mastered multi access. Speaking of human resources quality, education plays an important role in the process of improving the quality of human resources. Improving the quality of education is a process that is integrated with the process of improving the quality of human resources itself. In order to improve the quality of human resources the role of teachers as educators is required to be a professional.

The importance of the role of teachers is very important to determine the success of efforts to improve the quality of education, especially at the primary and secondary education levels. The role of teachers is concretely explained, that teachers more precisely have the philosophy and objectives of education, criteria for educational success, relevant educational sciences and theories, educational structure, curriculum, organization and educational leadership as well as educational financing. Undang-Undang Nomor 14 Tahun 2005 on Teachers and Lecturers affirms that teachers must have academic qualifications, competencies, educator certificates, physical and spiritual health, and have the ability to realize national educational objectives.

Professional teachers will produce quality educational processes and results in order to realize intelligent and competitive Indonesian people, namely people who believe and fear God Almighty noble, healthy, knowledgeable, capable, creative, independent, and become democratic and responsible citizens. Furthermore, Undang-Undang Republik Indonesia No. 20 Tahun 2003 concerning the National Education System Chapter XI Article 39 Paragraph 2 states that educators are professionals in charge of planning and carrying out the learning process, assessing learning outcomes, conducting mentoring and training as well as conducting research and community service, especially for educators in universities (Undang-Undang Republik Indonesia No. 20 Tahun 2003 Tentang Sistem Pendidikan Nasional, 2003).

In relation to teacher professionalism, article 10 of the Undang-Undang Republik Indonesia No. 14 Tahun 2005 concerning Teachers and Lecturers, teacher competencies include (1) pedagogic competencies, (2) professional competencies, (3) personality competencies and (4) social competencies. In relation to the term competency, in general provisions article 1 point 10 of the Law, it is stated that competence is a set of knowledge, skills, and behaviors that must be possessed, lived and mastered by teachers or lecturers in carrying out their professional duties.

Professionalism of teachers related to professional development work. Professional development work shows a work done by teachers. The work of professional development is one of the characteristics of professional teachers through a culture of writing and researching related to the quality of learning (process) which in turn improves the quality of education (output). Sustainable professional development is implemented through self-development, scientific publications, and/or innovative work. Sustainable professional development is implemented in accordance with the provisions stipulated by the Director General of.

Sustainable professional development is a process and activity designed to improve the knowledge, skills, and professional attitudes of teachers implemented in stages, stages, and continuously in order to improve the management and quality of education. Competence itself is an ownership of knowledge, skills and abilities demanded by a position or job, in this case a teacher. Competence refers to the behavioral dimension of a behavioral role that requires people to complete their work satisfactorily. Competency creates characteristics that can be demonstrated to distinguish high performance in roles specified under the topic as director, performance, team member and management. Competence is what people bring to a job in different forms and levels of behavior (Basri, 2005).

Teachers are required to meet certain qualifications and competencies so that they are able to carry out their duties professionally in accordance with their level. Based on Undang-Undang Nomor 14 Tahun 2005 on Teachers and Lecturers and Government Regulations on National Standards of Education, teachers are required to meet qualification criteria and competencies. For teachers at the high school education level and below qualifications are expected to be at least educated S1 / D4, while for teachers in higher education at least educated S2 / master. Competency, teachers are required to have 4 competencies, namely (1) professional or academic competencies, (2) pedagogical competencies, (3) social competencies, and (4) personality competencies (Undang-Undang Nomor 14 Tahun 2005, Tentang Guru Dan Dosen, 2005).

The efforts to improve these four competencies are efforts to improve teacher professionalism. As a consequence of the position of teachers as a profession, a system of coaching and development of the teacher profession is required in a programmatic and sustainable manner. Sustainable Professional Development / Pengembangan Keprofesian Berkelanjutan $(\mathrm{PKB})$ is one of the activities designed by the government to realize the formation of professional 
teachers. In addition, in accordance with the mandate of the Regulation of the Minister of State for Empowerment of State Apparatus and Bureaucratic Reform No. 16 of 2009, concerning the Functional Position of Teachers and their Credit Numbers, PKB is one of the main elements in the promotion and career development of teachers in addition to other activities relevant to the functions of the school.

Various studies related to the writing of scientific works including strategies, approaches, methods, and techniques have been widely discussed by experts (Bordens \& Abbott, 2002; Creswell, 2015) Teachers in general do not have scientific work because they are poorly trained on how to compose such scientific works. To improve this situation, teachers need to be given a strong enough stimulus through training and mentoring activities. Based on the analysis of the situation, a devotional activity entitled "Strengthening the Profession of Teacher Sustainability through Mentoring the Strengthening of Scientific Work of Teacher Learning". Through this activity, teachers, especially in target schools, can better understand the concept of $\mathrm{PKB}$ and further strive to carry out activities as much as possible that can improve professionalism as expected. Semarang State University as an institution that in theory handles the issue of research, scientific writing and scientific publications and community service feels the need to hold community service. The team of devotees to participate in the preparation of scientific publications which is a work of professional development through a workshop of scientific publications of teachers who in turn will produce a quality scientific work. With this workshop and mentoring, it is expected that the competence of teachers in the preparation of scientific publications will increase or increase.

Based on the observations, found various forms of problems faced in general are

1. limitations of professional development knowledge continued in teachers,

2. limitations in the development of writing scientific works as a form of learning innovation.

From the problems presented, it is necessary to do community service on the development of sustainable professional through the assistance of scientific works. Based on the above identification, the following problems are formulated.

1. How is the process of professional development sustainable through the writing of scientific works for teachers?

2. How does the contribution make to professional continuity through the writing of scientific works for teachers?

The objectives of community service activities are as follows.
1. Improving teacher competence in sustainable professional development through the writing of scientific works for teachers to improve the quality of learning.

2. Make a positive contribution to improving teacher competence, and improving the quality of school learning.

The benefit that can be obtained from this activity is to improve the competence of teachers in the development of sustainable professional through the writing of scientific works for teachers. Training on sustainable professional development through the writing of scientific works for teachers is expected to answer the problem of achieving the quality of superior teacher resources, as well as improving the quality of school learning that prioritizes the creation and development of science and technology.

\section{METHOD}

The problem faced by teachers in the classroom is the lack of knowledge and time related to the development of sustainable professionals in their respective institutions, one of the indicators to know the implementation of sustainable professional development activities in a school / madrasah is the number of teachers who rise through the ranks over time. In fact, from observations in some schools / madrasas there are still many teachers in the group IIId and IVa because of constraints on scientific publications and innovative works that are part of the sustainable professional development activities.

The lack of scientific publications and innovative work of teachers is due to the lack of socialization of sustainable professional development programs initiated by the government. In addition, the ability of teachers in writing scientific works both the results of research and the results of literature studies still need to be improved.

In essence, this activity is a solution to the problems faced by partners through an integrated approach, in order to improve competence in transferring knowledge and become motivators and facilitators in improving the ability of teachers in writing scientific works of learning innovation. Some of the problems faced by partners as revealed in the previous chapter, some alternative solutions that can be offered are as follows.

1. Socialization and exposure to the concept of sustainable professional development through the writing of scientific works to improve teacher learning innovations and teacher career advancements that can be applied in their schools.

2. Conducting workshops on sustainable professional development through the writing of 
scientific works, namely a team of service teachers in collaboration with teachers providing literature, laptops, then making simulations of research proposals.

This community service activity is intended to provide reinforcement to teachers in order to be able to develop critical and creative thinking skills in order to encourage the optimization of resources and the environment as well as the use of appropriate technology. The target of community service activities in teachers amounting to 250 teachers is to be able to complete scientific work proposals. Teachers must have knowledge and skills in the use of digital technology that prioritizes environmental friendliness. This training will be developed is a collaboration between teachers or educators who collaborate with the service as academics in the form of intensive mentoring. So that with the implementation of community service activities is not just a socialization.

The hope of changing conditions achieved is the improvement of teacher competence in writing innovative scientific works to improve teacher careers. In fact, teacher competency development activities with the assistance of sustainable professional development based on scientific work as a solution to partner problems through an integrated approach, in order to increase the intellectual value of capital and economic value that still needs to be developed optimally. Targets and externals in more detail can be described in the table of changes in conditions before and after the program of devotion in table 2 .

Table 2.

Expectations of Changes in Conditions Before and After the Service Program

\begin{tabular}{|c|l|l|l|}
\hline No. & \multicolumn{1}{|c|}{ Elcments } & \multicolumn{1}{c|}{ Pre-scrvicc } & \multicolumn{1}{c|}{ Post-scrvice } \\
\hline 1. & $\begin{array}{l}\text { Knowledge of the } \\
\text { concept of scientific } \\
\text { work of learning } \\
\text { innovation }\end{array}$ & $\begin{array}{l}\text { Not yet deeply } \\
\text { knowledgeable about the } \\
\text { concept of scientific work } \\
\text { of learning in schools }\end{array}$ & $\begin{array}{l}\text { Have at thorough and } \\
\text { in-depth knowledge of } \\
\text { the concept of scientitic } \\
\text { work of learning in } \\
\text { schools }\end{array}$ \\
\hline 2. & $\begin{array}{l}\text { Strengthening and } \\
\text { strengthening } \\
\text { teacher competence } \\
\text { in writing scientific } \\
\text { works of learning } \\
\text { innovation }\end{array}$ & $\begin{array}{l}\text { Teachers still have a lack } \\
\text { of confidence and } \\
\text { competence to develop } \\
\text { scientific writing } \\
\text { innovation lcarning }\end{array}$ & $\begin{array}{l}\text { Teachers are able to } \\
\text { develop scientific } \\
\text { writing of learning } \\
\text { imnovation in schools }\end{array}$ \\
\hline
\end{tabular}

This devotional activity is aimed at teachers at PAUD level up to high school. The solving model applied by community service teams is mentoring that generates skills through discussion, socialization and training. Teachers are expected to be able to understand and have knowledge and skills about the concept of sustainable professional development through the writing of scientific works, so as to be able to become a pilot project of educators / teachers of other civil servants so as to impact on career improvement and quality of learning in the classroom
The service team conducts activities in the place of service three (3) times with the details of the activities as follows.

1. Initial coordination, implemented in early April 2020. In this activity, the team of service to the community coordinates to know the extent of the general description of teacher knowledge on the concept of sustainable professional development through the writing of scientific works and how the process of developing teacher competence has been carried out.

2. Implementation of skills empowerment, knowledge transfer, socialization, discussion, training and with mentoring activities. This activity is carried out at the agreed time of both parties. Mentoring activities are carried out to know the sustainability of scientific writing training.

3. Periodic monitoring and mentoring. Monitoring and mentoring is periodically carried out after teachers and educational personnel have been able to understand the concept of writing scientific works. This activity is carried out to monitor the sustainability of the program of activities as well as the development of scientific work of innovative learning.

Realization of the implementation of the devotion model is the provision of material about the writing of scientific works of innovative learning. This is because of the general condition in the location where most teachers still have less knowledge and time. Hopefully with this devotion, teachers are able to perform better performance in the learning process, which will improve the quality of school learning.

\section{RESULTS AND DISCUSSIONS}

The implementation of devotion in this activity, experienced a change of concept because there is a global problem, namely pandemic Covid 19, which from the government of the Republic of Indonesia, especially from Permendikbud prohibits for the existence of joint associations in educational activities or tridarma colleges, therefore the implementation of which are all planned face-to-face, then replaced based in the network (Online). For the implementation and how the form of activities in more detail is as follows.

1. Coordination and Identification.

Coordination and Identification of the Process of Service Coordination activities were conducted in the room of the Department of Economic Education on Thursday, May 25, 2020. Coordination is carried out by the service team. Topics of coordination discussion 
related to the current condition of the real problems teachers face in the learning process, unresolved obstacles, classroom research writing strategies and research publications. The implementation of devotion in this activity, experienced a change of concept because there is a global problem, namely pandemic Covid-19, which from the government of the Republic of Indonesia, especially from Permendikbud prohibits for the existence of joint associations in educational activities or Tridharma universities, therefore the implementation of which are all planned face-to-face, then replaced based in the network (Online). For the implementation and how the form of activities in more detail is as follows.
Faculty of Economics, State University of Semarang. Then continued by the presenters namely Kemal Budi Mulyono, S.Pd., M.Pd., CIQnR. This workshop starts from 09.00 - 11.30 WIB. Exposure to materials starts from the strategy in writing class action research, starting from understanding class action research and its functions for careers and improving the learning process in the classroom, then continued with how to determine the real problems of learning to overcome, then strategies on how to choose learning solutions or learning methods to overcome learning problems in the classroom, and then end with how to write class action research reports and articles

Table 5.1

Class Action Research Workshop

2. Coordination and Identification of the Service Process.

Coordination activities were conducted in the Department of Economic Education on Thursday, May 25, 2020. Coordination is carried out by the service team. Topics of coordination discussion related to the current condition of the real problems teachers face in the learning process, unresolved obstacles, classroom research writing strategies and research publications.

\begin{tabular}{|c|c|c|}
\hline Time & Agenda & Person In Charge \\
\hline $08.00-08.30 \mathrm{WIB}$ & Participant Registration & \multirow{2}{*}{$\begin{array}{l}\text { Nina Farliana, S.Pd., } \\
\text { M.Pd. }\end{array}$} \\
\hline $08.30-09.00 \mathrm{WIB}$ & $\begin{array}{l}\text { 1. Opening } \\
\text { 2. Speech of The Committee Chairman of the } \\
\text { Service Team by Ubaedul Mustofa, S.H.I., } \\
\text { M.S.I } \\
\text { 3. Opening of The Head of Economic } \\
\text { Education Department, Faculty of } \\
\text { Economics, Semarang State University } \\
\text { 4. Pray }\end{array}$ & \\
\hline $09.00-10.30 \mathrm{WIB}$ & $\begin{array}{l}\text { Exposure of Strategy Materials to Research } \\
\text { and Publication of Effective and Efficient } \\
\text { Class Action Research by Kemal Budi } \\
\text { Mulyono, S.Pd., M.Pd. CIQnR }\end{array}$ & $\begin{array}{l}\text { Nina Farliana, S.Pd., } \\
\text { M.Pd. }\end{array}$ \\
\hline $10.30-11.15 \mathrm{WIB}$ & Dialogue and Q\&A & \multirow{2}{*}{$\begin{array}{l}\text { Nina Farliana, S.Pd., } \\
\text { M.Pd }\end{array}$} \\
\hline $11.15-11.30 \mathrm{WIB}$ & Closing & \\
\hline
\end{tabular}

Figure 1.

Coordination with the Team service

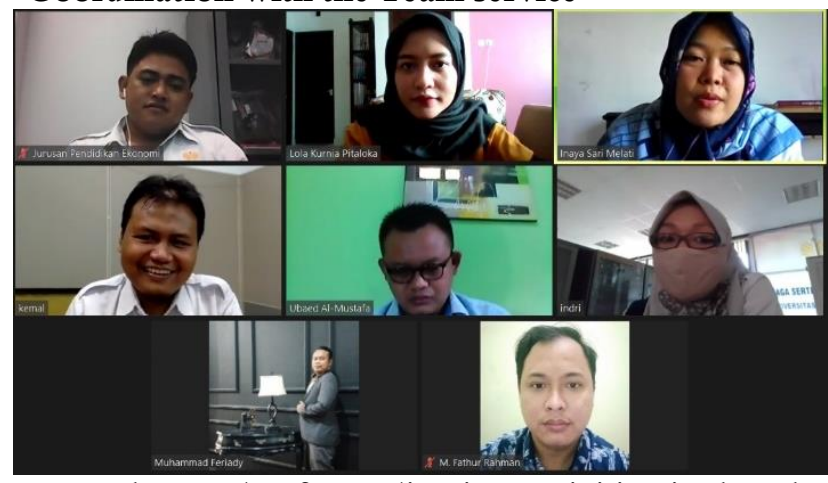

The result of coordination activities is that the event is carried out through from within the network / online this event is conducted because the current conditions are still in the pandemic corona / covid - 19 where the government prohibits to hold events that invite crowds, therefore, the event we play 3600 with all events we set online from all events this devotional activity.

\section{Class Action Research Workshop}

The next devotional program is a workshop on Strategy Researching and Publication of Effective and Efficient Class Action Research. This workshop was held on Tuesday, October 6, 2020. This was done considering the agreement and suitability of the schedule of this activity team was opened by the chairman of the Department of Economic Education,
Figure 2.

Speaker Material Exposure

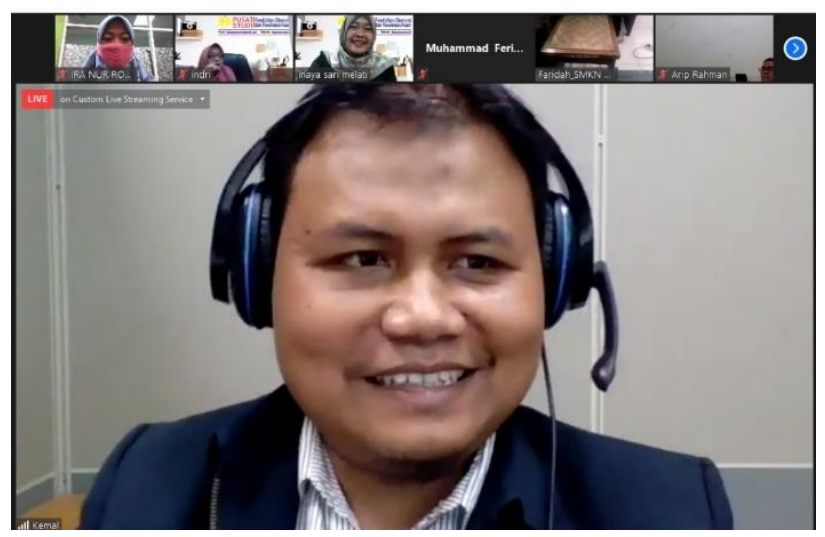

Figure 3.

Socialization Participants Listen to Material Exposure

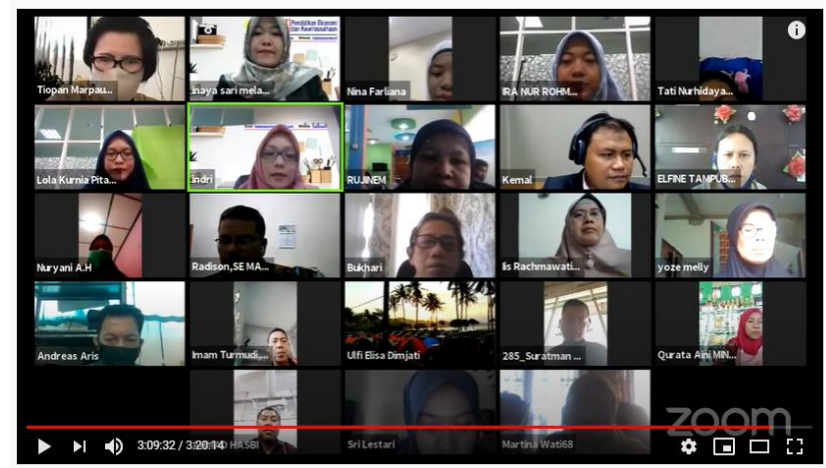


The implementation of the service of strengthening the profession of teacher sustainability through the assistance of strengthening scientific work of learning received an enthusiastic welcome from the participants. This is demonstrated by the support of all participants who are active in asking questions, as well as willing to continue in the next webinar event. With this training is expected to be able to write class action research reports as well as publications in journals recognized in the calculation of credit numbers. So that in the future teachers can prepare points for the increase in credit figures based on the publication of scientific works through class action research

\section{CONCLUSION}

Technical training strategy research and publication of effective and efficient class action research begins with the coordination stage followed by training and mentoring, simulation and evaluation of service programs. From these activities, the contribution resulting from the strengthening of the profession of teacher sustainability through the assistance of strengthening scientific work of learning is first, providing knowledge to teachers to improve the ability to write class action research. Second, cooperation between teachers and academics in developing education, especially the learning process in the classroom. Therefore, in the future, there needs to be awareness and participation of all teachers in writing and publishing class action research to improve the careers of teachers and improve the learning process. Involvement of all parties, namely teachers, principals and academics to play an active role in strengthening the process.

\section{REFERENCES}

Bordens, K. S., \& Abbott, B. B. (2002). Research Design and Methods: A Process Approach. McGraw-Hill.

Creswell, J. W. (2015). Educational Research Planning, COnducting, And Evaluating Quantitative and Qualitative Research - Fifth Edition. AORN Journal, 62(1), 668.

Undang-Undang Nomor 14 Tahun 2005, tentang Guru dan Dosen, (2005).

Undang-undang Republik Indonesia No. 20 Tahun 2003 tentang Sistem Pendidikan Nasional, (2003). 